Przegląd Prawa Konstytucyjnego

-------ISSN 2082-1212--------

DOI 10.15804/ppk.2014.06.03

$-\mathrm{Nr} 6(22) / 2014--------$

Katarzyna Tomaszewska ${ }^{1}$

\title{
Instrumenty ochrony interesu prawnego jednostki w ramach dostępu do informacji publicznej w świetle regulacji ustawy o dostępie do informacji publicznej oraz ustawy o planowaniu i zagospodarowaniu przestrzennym
}

Słowa kluczowe: dostęp do informacji publicznej, ochrona interesu prawnego jednostki, planowanie i zagospodarowanie

Keywords: access to public information, to protect the legal interests of individuals, planning and development

\section{Streszczenie}

Skłonność do poszukiwania i chęć zdobycia wiedzy stanowią rezultat podstawowej potrzeby egzystencjalnej jednostki. Chodzi w tym wypadku o zaspokojenie tzw. potrzeby poznania w drodze umożliwienia dostępu do tych informacji, które są jednostce potrzebne w danym miejscu i w danym czasie. Współcześnie dostęp do informacji publicznej jako pewnego rodzaju instytucja prawna stanowi nie tylko warunek istnienia demokratycznego państwa prawa, ale przede wszystkim jest sprawnym narzędziem realizacji licznych uprawnień obywatelskich. Zatem dokładne określenie, jakie instrumenty zawierają się w pojęciu powszechnego prawa do informacji na gruncie uregulowań ogólnych obowiązujących w niniejszym zakresie, jak również w zakresie uregulowań odnoszących się do konkretnej dziedziny życia jednostki, odgrywa istotne znaczenie dla funkcjonowania społeczeństwa informacyjnego. Określenie tego rodzaju

1 Autorka jest adiunktem w Centrum Badań Problemów Prawnych i Ekonomicznych Komunikacji Elektronicznej, Wydział Prawa, Administracji i Ekonomii, Uniwersytet Wrocławski.Mail: k.tomaszewska@prawo.uni.wroc.pl. 
środków, z jakich może skorzystać jednostka, bądź też które zostały stworzone z myślą o jednostce w ramach instytucji dostępu do informacji, w szczególności zaś w zakresie planowania i zagospodarowania przestrzennego, stanowi trzon rozważań prowadzonych w niniejszym opracowaniu.

\section{Summary}

\section{Instruments for the protection of legal interests of the individual in the context of access to public information in the light of the Law on Access to Public Information and in the Law on Spatial Planning and Development}

The tendency to seek knowledge and the desire to gain it is a result of basic existential needs of an individual. The idea is to fulfil the so-called cognitive needs by having access to information which an individual needs in a given place and at a given time. Nowadays, access to public information as a certain type of a legal institution is not only a condition for existence of a democratic rule of law but above all it is an efficient tool to implement numerous civil rights. Therefore, a precise definition of what instruments are included in the concept of common information law based on general rules applicable in the dis-cussed range, as well as in the range of regulations related to specific areas of an individual's life, plays an essential role in the functioning of an information society. Determination of measures which a unit can benefit from, or which have been created for an individual within the institution of access to information, in particular in the field of spatial planning and development, is the main subject of deliberations conducted in this paper.

\section{$*$}

Dostęp do informacji publicznej stanowi kategorię prawną, która współcześnie cieszy się żywym zainteresowaniem. Dzieje się to m.in. na skutek przypisywania procesowi udostępnienia informacji publicznej funkcji ochrony interesu prawnego jednostki. Obywatel ma prawo do uzyskiwania informacji o działalności organów władzy publicznej oraz o osobach pełniących funkcje publiczne. Uprawnienie to obejmuje również uzyskiwanie informacji o działalności organów samorządu gospodarczego i zawodowego, a także innych osób i jednostek organizacyjnych w zakresie, w jakim wykonują one zadania władzy publicznej i gospodarują mieniem komunalnym lub 
majątkiem Skarbu Państwa ${ }^{2}$. Jednostka bowiem, aby móc w pełni świadomie i racjonalnie podejmować indywidualne decyzje, musi posiadać właściwą wiedzę na temat otaczającego ją świata, zarówno w ujęciu strukturalnym, jak i funkcjonalnym, tj. również w zakresie podejmowanych rozstrzygnięć przez podmioty zarządzające $w$ państwie. Niewątpliwe nie budzi już żadnych wątpliwości założenie, w myśl którego skłonność do poszukiwania informacji stanowi naturalną potrzebę człowieka i obywatela, a dostęp do niej z uwagi na jej znaczenie jest nieodłącznym elementem społeczeństwa obywatelskiego, nierzadko współcześnie określanego mianem społeczeństwa informacyjnego ${ }^{3}$. Realizacja powszechnego prawa do informacji wiąże się z rozwojem demokracji postrzeganej jako ustrój państwa gwarantującego możliwość świadomego uczestniczenia jednostek w życiu całego społeczeństwa. Bez informacji dotyczących funkcjonowania podmiotów władzy publicznej obywatele nie byliby w stanie podejmować racjonalnych decyzji mających wpływ na ich życie i to w rozmaitych jego aspektach ${ }^{4}$. Państwo i działające w jego imieniu organy muszą zaspokajać zbiorowe i indywidualne potrzeby obywatelskie, a zatem są zobligowane do działania nie tylko na rzecz, ale również za akceptacją jednostek, dla której urzeczywistnienia istotnym jest zapewnienie dostępności do oczekiwanych informacji oraz stworzenie możliwości ich łatwego uzyskania. Wówczas bowiem obywatel może podejmować działania zgodne z jego aspiracjami lub też może przejawiać aktywność na tych polach, które mają chronić jego interesy. Co ważne, doniosłe znaczenie w tym zakresie posiada znajomość całokształtu okoliczności, w otoczeniu których ma być podejmowany owy akt działania lub

2 Zob. art. 61 Konstytucji RP (Dz.U. Nr 75, poz. 483 ze zm.).

3 Zob. M. Jaśkowska, Dostęp do informacji publicznej. Zagadnienia wybrane (materiat na konferencje sędziów NSA), Popowo 14-16 października 2002, Warszawa 2002, s. 1 i nast.; zob. również T. R. Aleksandrowicz, Komentarz do ustawy o dostępie do informacji publicznej, Warszawa, 2008; T. Gardocka, Obywatelskie prawo do informacji, Warszawa 2008; M. Zaremba, Prawo dostępu do informacji publicznej. Zagadnienia Praktyczne, Warszawa 2009.

4 Co istotne, prawo do informacji wynika również z rozmaitych ustaw, $\mathrm{w}$ tym przede wszystkim z kodeksów, które regulują przebieg procesu karnego czy też procesu cywilnego. W tym wypadku chodzi o prawo do informacji przysługujące stronom procesowym, a ustalenie jego rzeczywistego zakresu posiada znaczenie dla szeroko postrzeganej zasady kontradyktoryjności postępowania procesowego - zob. T. Gardocka, Obywatelskie prawo do informacji, Warszawa 2008, s. 11. 
też zaniechania. Powyższy stan rzeczy wymaga zapewnienia odpowiedniego dostępu do źródeł informacji i możliwości uzyskania tzw. wiedzy publicznej. Ich treść może oddziaływać nie tylko na aspekt życia prywatnego jednostki, ale przede wszystkim na płaszczyznę realizacji innych uprawnień, jakie przysługują obywatelom. Na podstawie niniejszego założenia można dopatrywać się istnienia aspektu ochrony interesu prawnego (w tym wypadku prawnie zagwarantowanego interesu informacyjnego) jednostki. Ponadto należy zauważyć, że obowiązujące prawo docenia rolę prawa do informacji jako elementu społecznego kontrolowania, dając jednocześnie podstawy do utożsamiania dostępu $\mathrm{z}$ instytucją służącą ochronie interesu prawnego jednostki w rozmaitych dziedzinach życia społecznego.

Nie bez znaczenia zatem pozostaje w tym miejscu założenie, w myśl którego wiedza o państwie, wiedza o sprawach publicznych, o podmiotach administrujących ma znaczenie praktyczne, albowiem stanowi podstawową przesłankę poczucia bezpieczeństwa obywatelskiego i ochrony zróżnicowanych interesów jednostek. Zagwarantowanie przez ustrojodawcę prawa do informacji (art. 61 Konstytucji RP, które podlega dalszemu rozwinięciu w drodze ustawy z dnia 6 września 2001 r. o dostępie do informacji publicznej - dalej zwaną u.d.i.p. $)^{5}$ stanowi podstawę procesu uświadamiania jednostek w przedmiocie tzw. spraw publicznych. Samo zaś dostarczenie wiedzy lub też umożliwienie jej zdobycia oddziałuje na indywidualne życie i interesy obywateli.

Należy jednak przy tym zaznaczyć, że niewątpliwie istotne znaczenie dla sprawnego funkcjonowania mechanizmu udostępniania informacji publicznej posiada należyta interpretacja jego instrumentów. A zatem przedmiotem niniejszych rozważań będzie dokonanie analizy tego rodzaju instrumentów na gruncie regulacji ogólnych (u.d.i.p) i ich skonfrontowanie z instrumentami występującymi na płaszczyźnie regulacji odnoszących się do planowania i zagospodarowania przestrzennego. Chodzi bowiem o ustalenie istniejących podobieństw oraz odmienności w tym zakresie i uwypuklenia elementów determinujących realizację ochrony interesu prawnego jednostki w ramach omawianej instytucji dostępu do informacji publicznej.

Ustawodawca tworząc generalną definicję informacji publicznej jako: „Każdej informacji o sprawach publicznych...”, dokonuje określenia do-

5 Dz.U. Nr 112, poz. 1198 ze zm. 
puszczalnych form udostępnienia tego rodzaju wiedzy. Według M. Jabłońskiego i K. Wygody: „Udostępnianie informacji publicznej może przybierać wiele postaci i przyjąć należy, że dopuszczalne są wszystkie środki przekazu, a w gestii żądającego pozostaje decyzja, z jakich będzie on chciał

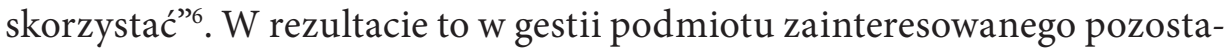
je decyzja, z jakiego instrumentu skorzysta dla zapewnienia ochrony własnego interesu informacyjnego.

Odnosząc się do regulacji konstytucyjnych kreujących sam fakt istnienia niniejszego uprawnienia, trzeba wskazać, że nakreślone w nich możliwości realizacji prawa do informacji (art. 61 ust. 2) zostały sformułowane szeroko i choć w tym miejscu nie posłużono się określeniem „w szczególności”, trzeba przyjąć, że posiadają one jedynie charakter przykładowy. Ponadto w żadnym razie nie można przyjąć, że ustrojodawca przy ich definiowaniu posłużył się określeniem „instrumentów ochrony interesu prawnego jednostki”, chociaż sama ich treść wskazuje na funkcję tzw. uświadamiania obywatelskiego w przedmiocie spraw publicznych. Co więcej, treść regulacji konstytucyjnych w tym przedmiocie nie definiuje również procesu udostępniania tego rodzaju informacji. Doktrynalne podejście względem omawianego zagadnienia wyraźnie wskazuje, że przez pojęcie dostępu należy rozumieć wszelkie dopuszczalne formy, przy pomocy których można zapoznać się z treścią dokumentów w formie bezpośredniej (tj. poprzez udostępnienie oryginału bądź jego kopii), jak również pośrednio (np. przy użyciu środków elektronicznego przekazu, tj. poprzez wgląd do dokumentu posiadającego postać elektroniczną) ${ }^{7}$. Analizując treść uregulowań ustawy zasadniczej w tym przedmiocie, trzeba nadmienić, że w ich świetle nie wprowadzono ograniczeń w kontekście dopuszczalnych form dostępu stanowiących instrumenty ochrony jednostki. Czyni to dopiero ustawodawca w u.d.i.p., albowiem konkretnie wskazuje, w jakich formach, w jaki sposób informacja tzw. publiczna może być udostępniona. Niemniej jednak analizując uprzednie zamierzenia i ostateczne rozstrzygnięcia ustawodawcy w przedmiocie dostępu do informacji, należy wskazać, że nie dokonuje on wyraźnego uwypuklenia i konkretnego nazwania instrumentów składających się na kon-

6 Zob. M. Jabłoński, K. Wygoda, Dostęp do informacji i jego granice, Wrocław 2002, s. 170.

7 Ibidem, s. 180. 
stytucyjne prawo do informacji, jako instytucji służącej ochronie interesu prawnego. Wskazuje natomiast na poszczególne elementy potwierdzające prawidłowość „zasady alternatywności” dostępu do informacji publicznej, związanej z uprawnieniem do samodzielnego decydowania w zakresie skorzystania z konkretnego instrumentu służącego ochronie jednostki.

W świetle art. 3 u.d.i.p. jednostka dla ochrony własnego interesu prawnego ma możliwość dokonania wyboru w przedmiocie przysługujących uprawnień, składających się na ustawowe prawo do informacji. Każde z nich urasta do rangi instrumentów ochrony interesu prawnego jednostki, albowiem prowadzi do uzyskania potrzebnej wiedzy, prowadzi do poszerzenia horyzontów, zgłębienia informacji szczególnie ważnych z uwagi na konkretną sytuację, w jakiej się ona znalazła ${ }^{8}$. Zgodnie ze wskazaną regulacją art. 3 u.d.i.p. powszechne prawo do informacji obejmuje uprawnienie do:

- Uzyskania informacji publicznej, w tym uzyskania informacji przetworzonej w takim zakresie, $\mathrm{w}$ jakim jest to szczególnie istotne dla interesu publicznego;

- Wglądu do dokumentów urzędowych;

- Dostępu do posiedzeń kolegialnych organów władzy publicznej pochodzących z powszechnych wyborów.

Przedstawiona powyżej klasyfikacja tworzy grupę tzw. instrumentów sensu stricto - instrumentów właściwych, składających się na samo zjawisko procesu udostępniania wiedzy publicznej. Niemniej jednak warto także zauważyć, że obok powyżej przedstawionych na uwagę zasługują również jako równoprawne instrumenty formy, przy pomocy których jednostka może realizować przysługujące jej prawo do informacji. Z racji ich istoty oraz roli, jaka została im przypisana, stanowią narzędzie, przy pomocy którego informacja publiczna objęta żądaniem podlega udostępnieniu. W efekcie $z$ uwagi na przyjęte rozważania można im przypisać charakter instrumentów ochrony interesu prawnego jednostki sensu largo. A w ramach ich grupy należy wymienić:

- Możliwość zapoznania się z informacją udostępnioną w drodze wyłożenia lub wywieszenia w miejscach ogólnie dostępnych;

8 Zob. M. Jabłoński, K. Wygoda, op.cit., s. 170. 
- Możliwość zapoznania się z informacją poprzez zainstalowanie w miejscach ogólnie dostępnych urządzeń umożliwiających poznanie jej treści;

- Możliwość zapoznania się z informacją umieszczoną w Biuletynie Informacji Publicznej';

- Możliwość zapoznania się z informacją umieszczoną w centralnym repozytorium.

W myśl powyższego udostępnienie informacji na gruncie uregulowań ogólnych może przybierać rozmaite postacie, a o samym wyborze formy decyduje wnioskodawca. Istotne znaczenie ma w tym wypadku precyzyjne skonkretyzowanie żądanej formy, albowiem podmiot zobowiązany nie może subiektywnie, tj. bez zgody wnioskodawcy, dokonać niniejszej zmiany. Podkreśla się zatem rolę samej jednostki zainteresowanej, poddając jej rozstrzygnięciu ostateczne skonkretyzowanie decyzji w tym zakresie. Jednostka nie jest zatem zdana tylko na to, co może jej zaoferować podmiot władzy publicznej, od którego żąda informacji określonego rodzaju. W sytuacji gdy wniosek jednostki w przedmiocie formy jest zbyt ogólny, wówczas podmiot zobowiązany może poinformować, że informacje objęte żądaniem jednostki znajdują się w jego siedzibie ${ }^{10}$. W ten sposób ustawodawca tworzy ogólny katalog moż-

9 Tworzy się urzędowy publikator teleinformatyczny - Biuletyn Informacji Publicznej - w celu powszechnego udostępnienia informacji publicznej w postaci ujednoliconego systemu stron w sieci teleinformatycznej - zob. art. 8 u.d.i.p, zob. też. Rozporządzenie Ministra Spraw Wewnętrznych i Administracji z dnia 18 stycznia 2007 r. w sprawie Biuletynu Informacji Publicznej (Dz.U. Nr 10, poz. 68).

10 Co istotne, $w$ tej sytuacji w żadnym razie podmiotowi zobowiązanemu nie można zarzucić bezczynności, albowiem jeżeli wnioskodawca w dalszej części postępowania zajmujący pozycję strony skarżącej zbyt ogólnikowo określił swoje żądanie co do formy udostępnienia, wówczas zajęcie stanowiska co do zaistniałej sytuacji przez podmiot władzy publicznej, które zostało zawarte w pisemnej informacji dotyczącej zapoznania się z przedmiotowymi dokumentami, spełnia przesłanki ich udostępnienia - zob. też Wyrok WSA wydany w Poznaniu z dnia 8 października 2008 r. (IV SAB/Po 14/08). Ale z przeciwnej strony, jeżeli żądanie wnioskodawcy dotyczy informacji, która obligatoryjnie powinna zostać zamieszczona w BIP, a z przyczyn bliżej nieznanych nie została tam umieszczona, wówczas jest to równoznaczne $\mathrm{z}$ bezczynnością $\mathrm{w}$ zakresie stosowania obligatoryjnej formy dostępu i podmiot zobowiązany przejmuje tym samym na siebie obowiązek udostępnienia informacji w trybie wnioskowym. W następstwie powyższego jednostka zainteresowana jest legitymowana do otrzymania informacji poprzez okazanie jej do naocznego zapoznania się lub też poprzez 
liwości, z jakich może i z jakich powinna skorzystać jednostka zainteresowana uzyskaniem konkretnej informacji publicznej. Niniejszy wachlarz z racji posiadania ogólnego charakteru interpretowanych regulacji ma zastosowanie we wszystkich dziedzinach administracji publicznej. Jednocześnie jednak podlega prawnym modyfikacjom wynikającym z uregulowań o charakterze szczególnym, właściwym dla konkretnego działu administracji publicznej.

Ustawa o planowaniu i zagospodarowaniu przestrzennym wraz z regulacjami ustawy z dnia 7 lipca 1994 r. - Prawo budowane ${ }^{11}$ oraz ustawy z dnia 21 sierpnia 1997 r. o gospodarce nieruchomościami ${ }^{12}$ są aktami tworzącymi podstawowy porządek odnoszący się do gospodarowania przestrzenią w Polsce. Proces planistyczny jest niezwykle ważny z punktu widzenia ingerencji w prawo własności $\mathrm{i}$ inne prawa do nieruchomości, co jest ściśle powiązane z art. 64 ust. 3 Konstytucji RP, który stanowi, że własność może być ograniczona tylko w drodze ustawy i tylko w takim zakresie, w jakim nie narusza ona istoty prawa własności.

Zasadniczym źródłem uregulowań dotyczących zasad planowania i zagospodarowania przestrzennego na terytorium RP jest ustawa $\mathrm{z}$ dnia 27 marca 2003 r. o planowaniu i zagospodarowaniu przestrzennym (dalej zw. u.p.i.z.p. $)^{13}$. Określa ona zasady kształtowania polityki przestrzennej przez jednostki samorządu terytorialnego i organy administracji rządowej. Przedmiotem jej uregulowań są także zasady i sposoby postępowania w sprawach przeznaczenia terenów na określone cele oraz ustalenia zasad ich zagospodarowania i zabudowy ${ }^{14}$.

otrzymanie wydruku, kopii dokumentacji oryginalnej, przesłania w postaci elektronicznej, w tym również skanu bądź nagrania - zob. M. Bernaczyk, Obowiązek bezwnioskowego udostępniania informacji publicznej, Warszawa 2008, s. 180.

11 Dz.U. 2013 poz. 1409 ze zm.

12 Dz.U. $2010 \mathrm{Nr} 102$, poz. 651 ze zm.

13 Dz.U. 2012 poz. 647 ze zm. Nie bez znaczenia jednak pozostają również regulacje odrębnych ustaw, takich jak ustawa z dnia 21 kwietnia 2001 r. - Prawo ochrony środowiska (Dz.U. 2013 poz. 1232).

14 Obok aktu rangi ustawy problematyka planowania i zagospodarowania przestrzennego odnajduje odzwierciedlenie również w następujących aktach wykonawczych: Rozporządzenie Ministra Infrastruktury z dnia 26 sierpnia 2003 r. w sprawie wymaganego zakresu projektu miejscowego planu zagospodarowania przestrzennego (Dz.U. Nr 164, poz. 1587), Rozporządzenie Ministra Infrastruktury z dnia 26 sierpnia 2003 r. w sprawie sposobu ustalenia wymagań dotyczących nowej zabudowy i zagospodarowania terenu w przypadku braku miejscowego planu zagospodarowania przestrzennego (Dz.U. Nr 164, poz. 1588), Rozporzą- 
Ustawodawca przewidując procedurę planistyczną, dąży do zabezpieczenia interesów rozmaitych podmiotów. Jeśli chodzi o interes ogólny, czyli interes ogółu społeczeństwa, istotne znaczenie odgrywają wartości określone w art. 1 ust. 2 u.p.i.z.p. W myśl bowiem niniejszego uregulowania wartości takie jak: wymagania ładu przestrzennego, w tym urbanistyki i architektury, walory architektoniczne i krajobrazowe, wymagania ochrony środowiska, wymagania dziedzictwa kulturowego itp. należy uwzględniać w procesie planowania i zagospodarowaniu przestrzennego kraju ${ }^{15}$. Z kolei z punktu widzenia dbałości o poszczególne jednostki na szczególną uwagę zasługuje uregulowanie zawarte w art. 6 u.p.i.z.p. W jego bowiem świetle ustawodawca determinuje istnienie ochrony interesów prawnych jednostek na płaszczyźnie procedury planowania i zagospodarowania terytorium RP. Co więcej, czyni to samodzielnie w ust. 2 przywołanej regulacji, albowiem: „Każdy ma prawo $\mathrm{w}$ granicach określonych ustawą do zagospodarowania terenu, do którego ma tytuł prawny, zgodnie z warunkami ustalonymi w miejscowym planie zagospodarowania przestrzennego, albo w decyzji o warunkach zabudowy i zagospodarowania terenu, jeżeli nie narusza to chronionego prawem interesu publicznego oraz interesu osób trzecich...”. Ponadto każdy ma prawo do ochrony własnego interesu prawnego przy zagospodarowaniu terenów należących do innych osób lub jednostek organizacyjnych.

Co istotne, na płaszczyźnie istniejących aktów planistycznych oraz w oparciu o ich tworzenie i realizację ustawodawca kreuje zbiór instrumentów, które mimo iż nie posiadają wyraźnie zdefiniowanego nazewnictwa jako tego rodzaju kategoria, służą zapewnieniu ochrony interesu prawnego jednostki w ramach dostępu do informacji publicznej. Co więcej, można pokusić się

dzenie Ministra Infrastruktury z dnia 26 sierpnia 2003 r. w sprawie oznaczeń i nazewnictwa stosowanych w decyzji o ustaleniu lokalizacji inwestycji celu publicznego oraz w decyzji o warunkach zabudowy (Dz.U. Nr 64, poz. 1589), Rozporządzenie Ministra Infrastruktury z dnia 28 kwietnia 2004 r. w sprawie zakresu projektu studium uwarunkowań kierunków zagospodarowania przestrzennego gminy (Dz.U. Nr 118, poz. 1233), Rozporządzenie Ministra Infrastruktury z dnia 13 maja 2004 r. w sprawie wzoru rejestru decyzji o warunkach zabudowy oraz rejestrów decyzji o ustaleniu lokalizacji inwestycji celu publicznego (Dz.U. $\mathrm{Nr}$ 130, poz. 1385), Rozporządzenie Ministra Infrastruktury z dnia 7 maja 2004 r. w sprawie sposobu uwzględniania w zagospodarowaniu przestrzennym potrzeb obronności i bezpieczeństwa państwa (Dz.U. Nr 125, poz. 1309).

15 Zob. też Z. Leoński, Materialne prawo administracyjne, Warszawa 2009, s. 117. 
o stwierdzenie, że jest to grupa tzw. instrumentów bezpośrednich. Stanowią one bowiem takie formy działania, których bezpośrednim i wyłącznym zadaniem jest zapewnienie możliwości przeciwdziałania nadużyciom ze strony podmiotów władzy publicznej w przedmiocie planowania oraz zagospodarowania terenu. Inaczej mówiąc, ich formalne wprowadzenie przez ustawodawcę wyłącznie i w zupełności zostało nakierowane na stworzenie jednostce możliwości dochodzenia swoich uprawnień, występowania z roszczeniami w oparciu o zaistniałe naruszenie czy też dla ochrony interesu prawnego. Jako przykład należy wymienić ustawowo zagwarantowaną możliwość składania uwag do projektu miejscowego planu zagospodarowania przestrzennego wyłożonego do publicznego wglądu ${ }^{16}$. W świetle obowiązujących uregulowań może je wnieść każdy, kto kwestionuje ustalenia przyjęte w projekcie planu, a więc mogą to czynić wszystkie podmioty, nawet jeśli nie posiadają w tym zakresie interesu prawnego. Przy czym należy podkreślić, że w ujęciu ogólnym konkretne działanie w obronie naruszonego interesu może posiadać charakter osobisty, jako personalna interwencja jednostki pokrzywdzonej, jak i również za pośrednictwem stosownego działania podmiotu publicznego ${ }^{17}$.

W ramach niniejszej grupy należy wymienić następujące elementy:

- ogłoszenie o podjęciu uchwały o przystąpieniu do sporządzenia stadium uwarunkowań i kierunków zagospodarowania przestrzennego gminy $^{18}$ (art. 11 ust.1 zd.1 u.p.i.z.p. ${ }^{19}$;

16 Trzeba jednak w tym miejscu zauważyć, że składane do projektu planu uwagi nie posiadają charakteru informacji publicznej. Nie stanowią bowiem dokumentu urzędowego wytworzonego przez organy władzy publicznej, jak również nie odnoszą się do podmiotu władzy publicznej ani też nie są stosowane przez podmioty władzy publicznej w realizacji zadań publicznych. Do czasu ich rozpatrzenia nie wywołują żadnych skutków prawnych. Nie można zatem uznać za zasadne, że stanowią one informację publiczną znajdującą się w posiadaniu organu - zob. Wyrok WSA z dnia 2 grudnia 2009 r. wydany we Wrocławiu (IV SAB/Wr62/09).

17 Z kolei za instrumenty ochrony pośredniej można uznać takie formy działania, których bezpośrednia rola nie wiąże się z ochroną interesu jednostki, choć ich istnienie posiada istotne znaczenie dla ogółu społeczności.

18 Co istotne, studium uwarunkowań i kierunków zagospodarowania przestrzennego nie jest aktem powszechnie obowiązującym, ale ustalenia w nim zawarte wiążą organy gminy przy prowadzonych działaniach nad sporządzeniem miejscowego planu zagospodarowania przestrzennego.

19 Co istotne, odbywa się ono z jednoczesnym zawiadomieniem na piśmie o podjęciu uchwały o przystąpieniu do sporządzenia studium instytucje i organy właściwe do uzgadniania i opiniowania projektu studium (art.11 ust. 2 u.p.i.z.p.). 
- określenie formy, miejsca i terminu składania wniosków dotyczących studium uwarunkowań i kierunków zagospodarowania przestrzennego gminy, który nie może być krótszy niż 21 dni od dnia ogłoszenia (art. 11 ust. 1 zd. 2 u.p.i.z.p.);

- ogłoszenie o wyłożeniu projektu studium uwarunkowań i kierunków zagospodarowania przestrzennego gminy do publicznego wglądu celem zapewnienia możliwości zapoznania z jego treścią i przeprowadzenia publicznej dyskusji (art. 11 ust. 10 u.p.i.z.p.);

- zjawisko faktycznego wyłożenia do publicznego wglądu projektu studium uwarunkowań i kierunków zagospodarowania przestrzennego gminy oraz jego publikacja na stronach internetowych urzędu gminy przez okres trwający co najmniej 21 dni (art. 11 ust. 10 u.p.i.z.p.);

- wyznaczenie terminu (nie krótszego niż 21 dni od dnia zakończenia okresu wyłożenia projektu studium) umożliwiającego wniesienie uwag do projektu studium przez osoby fizyczne, prawne i jednostki organizacyjne nieposiadające osobowości prawnej (art. 11 ust. 11 u.p.i.z.p.);

- $\quad$ ogłoszenie o podjęciu uchwały o przystąpieniu do sporządzenia miejscowego planu zagospodarowania gminy ${ }^{20}$ (art. 17 ust. 1 u.p.i.z.p.) $)^{21}$;

- określenie formy, miejsca i terminu składania wniosków dotyczących planu zagospodarowania przestrzennego gminy, który nie może być krótszy niż 21 dni od dnia ogłoszenia (art. 17 ust. 1 u.p.i.z.p.);

- ogłoszenie o wyłożeniu do publicznego wglądu projektu miejscowego planu zagospodarowania przestrzennego gminy ${ }^{22}$ celem zaznajo-

20 Integralną częścią niniejszej uchwały jest graficzny załącznik określający granice administracyjne obszaru objętego projektem ustalanego miejscowego planu zagospodarowania przestrzennego.

${ }^{21}$ Z niniejszą czynnością organu wykonawczego w gminie skorelowane jest zobowiązanie w zakresie jednoczesnego zawiadomienia na piśmie o podjęciu uchwały o przystąpieniu do sporządzenia planu instytucje i organy właściwe w sprawie uzgadniania i opiniowania planu (art. 17 ust. 2 u.p.i.z.p.).

22 Występujący na poziomie gminy miejscowy plan zagospodarowania przestrzennego jest aktem, w ramach którego dochodzi do ustalenia przeznaczenia terenów oraz sposobów ich zagospodarowania i zabudowy. 
mienia się z rozwiązaniami przyjętymi w jego treści i przeprowadzenia publicznej dyskusji ${ }^{23}$ (art. 17 ust. 9 u.p.i.z.p.);

- zjawisko faktycznego wyłożenia do publicznego wglądu projektu miejscowego planu zagospodarowania przestrzennego gminy wraz z prognozą oddziaływania na środowisko na okres trwający co najmniej 21 dni (art. 17 ust. 9 u.p.i.z.p.);

- wyznaczenie terminu (nie krótszego niż 14 dni od dnia zakończenia okresu wyłożenia projektu planu) umożliwiającego wniesienie uwag do projektu planu przez osoby fizyczne, prawne i jednostki organizacyjne nieposiadające osobowości prawnej (art. 17 ust. 11 u.p.i.z.p.) ${ }^{24}$;

- ogłoszenie uchwały w sprawie uchwalenia miejscowego planu zagospodarowania przestrzennego gminy w wojewódzkim dzienniku urzędowym oraz opublikowania jej na stronie internetowej gminy ${ }^{25}$ (art. 29 ust.1 i ust 2 u.p.i.z.p.);

- $\quad$ ogłoszenie o podjęciu uchwały o przystąpieniu do sporządzenia planu zagospodarowania przestrzennego województwa (art. 41 ust. 1 u.p.i.z.p.) ${ }^{26}$;

23 Projekt miejscowego planu zagospodarowania przestrzennego gminy musi być zgodny z ustaleniami zawartymi w studium oraz z treścią odrębnych uregulowań odnoszących się również do obszaru objętego projektowanym planem. Podobnie jak w przypadku studium, opracowanie projektu miejscowego planu zagospodarowania przestrzennego jest projektowaniem w skali lokalnej, a zatem projektowaniem wymagającym działania uprawnionego w tym zakresie urbanisty.

24 Co istotne, uwagi do projektu planu może wnieść każdy, kto kwestionuje ustalenia przyjęte w projekcie planu wyłożonym do publicznego wglądu. Uwagi należy wnieść na piśmie. Za formę pisemną uważa się wniesienie uwag w postaci elektronicznej opatrzone bezpiecznym podpisem elektronicznym weryfikowanym przy pomocy ważnego kwalifikowanego certyfikatu w rozumieniu ustawy z dnia 28 września 2001 r. o podpisie elektronicznym (Dz.U. 2013 poz. 262) lub opatrzone podpisem potwierdzonym profilem zaufanym e PUAP w rozumieniu przepisów ustawy z dnia 17 lutego 2005 r. o informatyzacji działalności podmiotów realizujących zadnia publiczne (Dz.U. 2013 poz. 235 ze zm.) bądź też za pomocą elektronicznej skrzynki podawczej w rozumieniu przepisów ustawy z dnia 17 lutego 2005 r. o informatyzacji działalności podmiotów realizujących zadania publiczne (Dz.U. 2013 poz. 235 ze zm.).

25 Co ważne, tego rodzaju publikacji ustawodawca nie przewidział w odniesieniu do innych aktów prawa miejscowego. Trzeba jednak nadmienić, że w rzeczywistości nie chodzi w tym wypadku o publikację treści planu, ale o podanie aktu do publicznej wiadomości.

26 Wraz z przedmiotowym ogłoszeniem marszałek województwa zawiadamia na piśmie o podjęciu uchwały o przystąpieniu do sporządzenia planu instytucje i organy właściwe do uzgadniania i opiniowania planu (art. 41 usta. 2 u.p.i.z.p.). 
- określenie formy, miejsca i terminu składania wniosków dotyczących planu zagospodarowania województwa, który nie może być krótszy niż 3 miesiące od dnia jego ogłoszenia (art. 41 ust. 1 u.p.i.z.p.);

- ogłoszenie uchwały o uchwaleniu planu zagospodarowania przestrzennego województwa w wojewódzkim dzienniku urzędowym ${ }^{27}$ (art. 42 ust. 2 u.p.i.z.p.);

- zawiadomienie o wszczęciu postępowania w sprawie wydania decyzji o ustaleniu lokalizacji inwestycji celu publicznego ${ }^{28}$ oraz zawiadomienie o wszelkich podjętych postanowieniach i decyzji kończącej to postępowanie (art. 53 ust. 1 u.p.i.z.p.) ${ }^{29}$.

Przedstawione instrumenty bez wątpienia wyczerpują znamiona konstrukcji dostępu do informacji publicznej. Należy jednak przy tym podkreślić, że z wyjątkiem elementu wyłożenia do publicznego wglądu nie można $\mathrm{w}$ ich zakresie mówić o procedurze, która stanowiłaby powielenie uregulowań zawartych w u.d.i.p. W każdym natomiast $\mathrm{z}$ wymienionych chodzi o umożliwienie jednostce zapoznania się z treścią tych informacji, które ze względu na swoją zawartość merytoryczną odnoszą się do kategorii spraw publicznych. Biorąc pod uwagę stanowisko B. Dolnickiego, można pokusić się o stwierdzenie, że stanowią one potwierdzenie deklaracji jawności życia publicznego, która na tym właśnie gruncie rządzi się własnymi prawa-

27 Plan zagospodarowania przestrzennego województwa podobnie jak studium uwarunkowań i kierunków zagospodarowania gminy nie jest aktem prawa miejscowego, nie jest aktem powszechnego obowiązywania, a zatem nie może bezpośrednio wpływać na uprawnienia i obowiązki obywateli. Z przeciwnej jednak strony należy uznać, że w stosunku do gminy jego treść jest wiążąca w określonym zakresie odnoszącym się do opracowywania studium. W żadnym jednak razie nie może stanowić podstawy do wydania decyzji administracyjnej - zob. Wyrok WSA w Warszawie z dnia 8 listopada 2007 r., IV SA/Wa 558/07.

28 W związku z brakiem miejscowego planu zagospodarowania przestrzennego ustawodawca posługuje się również kategorią decyzji o ustaleniu warunków zabudowy. W myśl art. 59 ust. 1 u.p.i.z.p. występuje ona w przypadku zmiany zagospodarowania terenu. Niniejsza zmiana może polegać na budowie obiektu budowlanego lub wykonaniu innych robót budowlanych bądź też może polegać na zmianie sposobu użytkowania terenu lub jego określonej części.

29 Zawiadomienie inwestora oraz właścicieli i użytkowników wieczystych nieruchomości, na których będą realizowane inwestycje celu publicznego, następuje na piśmie (art. 53 ust. 1 zd. 2 u.p.i.z.p.). 
$\mathrm{mi}^{30}$. Co jednak ważne, analizując ich zawartość merytoryczną względem spełniania funkcji ochronnej względem interesu prawnego jednostki, należy zwrócić uwagę, że jako tego rodzaju kategoria nie posiadają charakteru uprawnienia, czy też możliwości, z których jednostka może bezpośrednio skorzystać. Wręcz przeciwnie, sprowadzają się do kategorii ustawowego zobowiązania podmiotów władzy publicznej, od uchylenia się których nie ma możliwości, a które tworzą podstawy do podejmowania konkretnych działań przez jednostkę. Ustawodawca bowiem nie tylko obliguje przedmiotowe organy do działania $\mathrm{z}$ urzędu, ale również określa kluczowe elementy spełnienia niniejszego zobowiązania, takie jak termin, sposób czy też forma realizacji. W żadnym jednak razie nie można przyjąć, że posiadanie niniejszego charakteru pozbawia je czy też umniejsza ich znaczenie jako elementów służących ochronie interesu prawnego jednostki. Przeciwnie, posiadając obligatoryjny charakter, tworzą zasadniczą grupę instrumentów realizacji dostępu do informacji publicznej na płaszczyźnie planowania, a tym samym i ochrony interesu informacyjnego jednostki.

Jak wynika to $\mathrm{z}$ uprzednio przedstawionych rozważań, ustawodawca na gruncie u.p.i.z.p. determinuje sposoby realizacji zobowiązań podmiotów władzy publicznej, zawierających się w pojęciu dostępu do informacji publicznej. Co istotne, zasadniczą formą służącą realizacji niniejszych zobowiązań jest instytucja podawania do publicznej wiadomości. Należy przy tym zauważyć, że z punktu widzenia regulacji u.d.i.p podawanie do publicznej wiadomości stanowi szczególną formę udostępniania „wiedzy”. Co więcej, jest formą, która nie znajduje swojego zastosowania na płaszczyźnie regulacji u.d.i.p. Z kolei przeciwnie do uregulowań ogólnych w omawianym przedmiocie regulacje materialnego prawa administracyjnego przewidują szereg sytuacji, w ramach których „obowiązek informacyjny” sprowadza się do podawania do publicznej wiadomości. Trzeba jednak podkreślić, że dzieje się to bez jego konkretnego zdefiniowania, bez konkretnego określenia, na czym ma w rzeczywistości polegać. Podawanie do publicznej wiadomości jest pojęciem szerokim i nieostrym. Obejmuje swoim zakresem rozmaite czynności materialno-techniczne, które mogą sprowadzać się do przekazywania różnego rodzaju informacji.

30 Zob. B. Dolnicki, Zasady jawności i dostępu do informacji publicznej jako czynnik przeciwdziałania biurokratyzowaniu się administracji, [w: Biurokracja, III Międzynarodowa Konferencja Naukowa, Krynica, 2-4 czerwca 2006 r., Rzeszów, 2006, s. 116. 
Z punktu widzenia prowadzonych rozważań należy zauważyć, że w sytuacji zupełnego braku zdefiniowania formy podawania do publicznej wiadomości ogłoszenie w Biuletynie Informacji Publicznej wydaje się najbardziej korzystne i to $\mathrm{z}$ niego należałoby skorzystać.

Co jednak ważne, niniejsze założenie nie ma zastosowania na gruncie u.p.i.z.p. W świetle bowiem omawianych uregulowań ustawodawca determinuje fizyczną postać podawania do publicznej wiadomości, wskazując, że polega ono na:

- $\quad$ ogłoszeniu w prasie miejscowej (w prasie ogólnopolskiej, jeśli chodzi o regulacje planistyczne na szczeblu województwa);

- obwieszczeniu bez jego szczegółowego określenia na poziomie ustawy (jeśli chodzi o regulacje planistyczne na szczeblu gminy) oraz na obwieszczeniu w urzędach gmin, w starostwach powiatowych, w urzędzie marszałkowskim oraz w urzędzie wojewódzkim (jeśli chodzi o ogłoszenie uchwały dotyczącej planu zagospodarowania przestrzennego województwa);

- do innego sposobu zwyczajowego upubliczniania wiedzy, stosowanego na danym terytorium państwa ${ }^{31}$.

Analizując ich charakter, trzeba wskazać, że są to typowe formy upubliczniania informacji członkom danej społeczności samorządowej. One niewątpliwe podkreślają lokalny charakter udostępniania wiedzy, wynikający chociażby z zamieszkiwania mieszkańców na terytorium danej jednostki administracyjnej państwa. Ponadto ich stosowanie umożliwia zachowanie integralności istniejącego zwyczaju, do którego są przyzwyczajeni mieszkańcy określonej części państwa. Ma to szczególne znaczenie w społecznościach małych - wiejskich, gdzie zwyczajowe miejsca i sposoby umieszczania ogłoszeń są od lata znane i akceptowane ${ }^{32}$. Niewątpliwie

31 Wzory ogłoszeń, obwieszczeń, zawiadomień zarówno w odniesieniu do działań związanych ze studium uwarunkowań i kierunków zagospodarowania przestrzennego, jak i z miejscowym planem zagospodarowania przestrzennego określają: Rozporządzenie Ministra Infrastruktury z dnia 28 kwietnia 2004 r. w sprawie zakresu projektu studium uwarunkowań i kierunków zagospodarowania przestrzennego gminy (Dz.U. Nr 118, poz. 1233) oraz Rozporządzenie Ministra Infrastruktury z dnia 26 sierpnia 2003 r. w sprawie wymaganego zakresu projektu miejscowego planu zagospodarowania przestrzennego (Dz.U. Nr 164, poz. 1587).

32 Wyjątek stanowi przywołana forma wyłożenia, wywieszenia do publicznego wglądu, która występuje na gruncie uregulowań ogólnych w przedmiocie udostępniania informacji publicznych. 
za ich pomocą ustawodawca kreuje możliwość namacalnego - naocznego, faktycznego zapoznania się z treścią przygotowanych projektów aktów planistycznych. Co istotne, niniejsze formy mimo iż nie stanowią powielenia uregulowań ogólnych ${ }^{33}$, odpowiadają założeniom przedmiotowym procesu udostępnienia informacji publicznych. Innymi słowy, odnosząc niniejsze rozważania na grunt interpretacji instrumentów w świetle regulacji u.d.i.p., należy wskazać, że przedstawione powyżej formy wyczerpują znamiona instrumentów sensu largo, czyli instrumentów, przy pomocy których jednostka ma możliwość zapoznania się z treścią „dokumentacji”, która jeszcze nie obowiązuje i dzięki czemu ma możliwość wypowiedzenia się, a tym samym i częściowego wpływu na ostateczne ukształtowanie jej treści. Tym samym ustawodawca umożliwia ochronę interesów obywatelskich, nie tylko za pomocą wprowadzonego "procesu informacyjnego", ale także na skutek stworzenia jednostce możliwości w zakresie wyrażenia własnego poglądu. Trzeba zatem podkreślić, że w niniejszy sposób dochodzi do stworzenia jednostce warunków ochrony zgodnie z przyjętym założeniem, w myśl którego: „...każdy ma prawo do... ochrony własnego interesu przy zagospodarowaniu terenów...", przy jedoczesnym wykazywaniu dbałości o interesy innych osób, również zamieszkujących na tym samym obszarze jednostki samorządu terytorialnego.

$\mathrm{Na}$ tym etapie prowadzonych rozważań pojawia się jeszcze jedno zasadnicze pytanie, a mianowicie chodzi o ustalenie, czy zamieszczanie informacji w sposób zwyczajowo przyjęty wyklucza możliwość jednoczesnego - równoległego zamieszczenia informacji w Biuletynie Informacji Publicznej. Jeżeli bowiem przepis szczególny przewiduje ogłoszenie, wyłożenie, wywieszenie czy też podanie do publicznej wiadomości w sposób zwyczajowo przyjęty w danej miejscowości i jednocześnie milczy o możliwości zamieszczenia tej samej wiedzy w BIP, nie dochodzi do naruszenia obowiązku wynikającego z treści art. 8 ust. 3 zd. 2 u.d.i.p. ${ }^{34}$ Innymi słowy, należy zwrócić uwagę na ustawową dopuszczalność ogłoszenia w BIP in-

33 Zob. też P. Sitniewski, Ustawa o dostępie do informacji publicznej. Komentarz, Wrocław 2011, s. 173.

34 Potwierdzenia niniejszego można upatrywać na płaszczyźnie art. 11 ust. 10 u.p.i.z.p., $\mathrm{w}$ ramach to którego mowa jest o publikacji projektu studium uwarunkowań i zagospodarowania przestrzennego na stronach internetowych gminy. 
nych informacji o znamionach wiedzy publicznej, które wykraczają poza zakres określony w art. 6 ust. 1 pkt 1-3, pkt. lit. a tiret drugie, lit. c, lit. d i pkt. 5 u.d.i.p. ${ }^{35}$ Trzeba jednak podkreślić, że w niniejszej sytuacji zawiadomienie o fakcie zamieszczenia danych informacji w BIP powinno również zostać umieszczone w tym miejscu, w którym pierwotnie informacje miały być zwyczajowo udostępnione.

Ponadto z punktu widzenia prowadzonej analizy, choćby $\mathrm{z}$ uwagi na odmienność względem uregulowań ogólnych w omawianym przedmiocie, warto zwrócić uwagę na instytucję zawiadamiania o wszczęciu postępowania w sprawie wydania decyzji o ustaleniu lokalizacji inwestycji celu publicznego oraz o postanowieniach i ostatecznej decyzji zapadłej jako rozstrzygnięcie postępowania. W myśl uregulowań u.p.i.z.p. zawiadomienie stron odbywa się w drodze obwieszczenia, jak również w inny sposób zwyczajowo przyjęty w danej miejscowości. Niniejsze formy z racji już ich uprzedniego występowania na gruncie u.p.i.z.p. nie budzą wątpliwości. Odmienność procesu udostępniania pojawia się natomiast w kontekście zawiadamiania inwestora oraz właścicieli i użytkowników wieczystych nieruchomości, na których będą lokalizowane inwestycje celu publicznego. W ich bowiem przypadku ustawodawca przewidział szczególną formę zawiadamiania na piśmie ${ }^{36}$. Co więcej, niniejsze zawia-

\footnotetext{
35 Zob. art. 8 ust. 1 pkt. 3 u.d.i.p.
}

36 Podobnej sytuacji można upatrywać na gruncie regulacji ustawy z dnia 7 września 1991 r. o systemie oświaty (Dz.U. 2004 Nr 256, poz. 2572 ze zm. - dalej: SystOśwU). Dyrektor szkoły publicznej, mimo iż nie jest organem władzy publicznej sensu stricto, w świetle regulacji u.d.i.p. należy do grupy podmiotów zobowiązanych w przedmiocie udostępnienia informacji publicznej. Potwierdzeniem powyższego jest art. 39 ust. 1 pkt. 5 SystOśwU, w świetle którego dyrektor szkoły dysponuje środkami określonymi w planie finansowym szkoły... i z racji tego ponosi odpowiedzialność za ich prawidłowe wykorzystanie, a także może organizować administracyjną, finansową i gospodarczą obsługę szkoły. A zatem w związku z przedstawionymi funkcjami dyrektor szkoły jest zobowiązany również w zakresie udostępnienia informacji publicznej w sposób określony przez ustawodawcę. Regulacje objęte analizą wskazują na szczególną formę udostępnienia informacji, a mianowicie na zawartą w art. $7 \mathrm{~d}$ oraz w art. 59 ust 1 . konstrukcję zawiadomienia. Co istotne, element zawiadomienia (jako instrument ochrony interesu prawnego jednostki zawierający się w konstrukcji dostępu do informacji publicznej) na gruncie uregulowań poświęconych systemowi oświaty dotyczy sytuacji dwojakiego rodzaju. Po pierwsze chodzi o kwestie poinformowania zainteresowanych (w tym przypadku rodziców działających w imieniu i na rzecz bezpośrednich 
domienie nie może zostać zastąpione procesem wywieszenia informacji w miejscu publicznym, powszechnie dostępnym. Skuteczne powiadomienie ma miejsce tylko wówczas, gdy jest skierowane bezpośrednio do samych zainteresowanych - inwestora, właściciela, użytkownika wieczystego. Tylko bowiem wówczas daje ono gwarancję dotarcia konkretnej informacji do właściwego adresata. Niniejsza sytuacja stanowi przykład specyficznego sposobu realizacji zobowiązania informacyjnego. Co więcej, w żadnym razie nie może być wypierana przez publikację informacji w Biuletynie Informacji Publicznej. Ogłoszenie w BIP niewątpliwie sta-

adresatów regulacji) o procesie likwidacji szkoły, czy też po drugie poinformowania o zamierzonym przeniesieniu kształcenia w określonym zawodzie z jednej szkoły lub placówki do innej szkoły lub innej placówki. Zgodnie z art. 59 ust. 1 SystOśwU szkoła publiczna jako jednostka oświatowa może być zlikwidowana z końcem roku szkolnego po uprzednim zapewnieniu przez podmiot prowadzący szkołę o możliwości kontynuowania nauki w innej szkole publicznej tego samego typu, jak również odpowiednio o tym samym lub zbliżonym profilu kształcenia ogólno-zawodowego albo kształcącej w tym samym lub zbliżonym zawodzie. Ten sam podmiot $\mathrm{z}$ racji jego zakwalifikowania do grupy podmiotów zobowiązanych informacyjnie jest obarczony powinnością zawiadomienia na co najmniej 6 miesięcy przed terminem likwidacji o swoim zamiarze rodziców lub bezpośrednio samych zainteresowanych uczniów (w odniesieniu do szkół publicznych dla dorosłych). Ten sześciomiesięczny termin, o którym mowa powyżej, dotyczy również obowiązku zawiadomienia rodziców lub bezpośrednio samych zainteresowanych o zamiarze przeniesienia kształcenia z jednego miejsca do innego, który także spełnia odpowiednie warunki nauczania zawodu. Z kolei sytuacja drugiego rodzaju jest zbliżona do uprzednio omówionych, albowiem art. 7d dotyczy kwestii likwidacji oddziału międzynarodowego, utworzonego w szkole publicznej, o której to likwidacji (o zamiarze jej dokonania) podmiot prowadzący jest zobowiązany poinformować rodziców uczniów do niego uczęszczających. Zawiadomienie w tym przypadku stanowi dominującą i jednocześnie nadrzędną formę realizacji dostępu do informacji publicznej. W żadnym razie nie może zostać spełnione w drodze wywieszenia tego rodzaju informacji w miejscach ogólnie dostępnych. Skuteczność realizacji zobowiązania informacyjnego w tym wypadku została zdeterminowana dokonaniem zawiadomienia skierowanego do ściśle spersonalizowanego adresata. Co istotne, nie jest to możliwe, aby mogło być zastąpione formą „podania do publicznej i powszechnej informacji” zainteresowanych. Na szczególną uwagę w tym miejscu zasługuje wyrok NSA, w którym to sąd stwierdził: „...że nie jest dopuszczalnym uznanie za wystarczającą formę poinformowania rodziców, na gruncie takiej argumentacji, gdzie sprawa stanowiła przedmiot publicznej debaty i obrad rady miejskiej oraz że informacja została udostępniona również w lokalnym radio i telewizji, w związku z czym każdy mieszkaniec, a tym samym każdy zainteresowany, mógł się z tego rodzaju informacją zapoznać” - zob. Wyrok NSA z dnia 18 kwietnia 2001 r. (SA/Sz/149/01). 
nowi najprostszą i najefektywniejszą formę realizacji powszechnego prawa do informacji, niemniej jednak nieposiadającą zastosowania w tym konkretnym przypadku.

Zgodnie z treścią art. 30 ust. 1: „Każdy ma prawo do wglądu do studium lub planu miejscowego oraz otrzymania z nich wypisów i wyrysów". $\mathrm{Na}$ gruncie niniejszego uregulowania ustawodawca również potwierdza aspekt ochrony interesu informacyjnego jednostki. Co więcej, posługując się pojęciem „każdego”, potwierdza przysługujące jednostce prawo do uzyskania informacji publicznej i nawiązuje do uregulowań ogólnych obowiązujących $\mathrm{w}$ niniejszym przedmiocie.

$\mathrm{Na}$ tym etapie warto pokrótce przyjrzeć się samemu procesowi ogłaszania aktów planistycznych, a ściślej procesowi ogłaszania miejscowego planu zagospodarowania przestrzennego. W przeciwieństwie do studium uwarunkowań i kierunków zagospodarowania przestrzennego niniejszy plan jest aktem prawa miejscowego obowiązującym na obszarze danej jednostki samorządu terytorialnego. Treść obowiązującego prawa (w tym wypadku prawa miejscowego) w sposób oczywisty i niepodważalny zawiera się w pojęciu informacji publicznej. Niemniej jednak należy podkreślić, że jako tego rodzaju dokumentacja podlega odmiennym uregulowaniom odnoszącym się do procesu udostępniania. Podstawową regulacją w tym przedmiocie jest ustawa z dnia 20 lipca 2000 r. o ogłaszaniu aktów normatywnych i niektórych innych aktów prawnych ${ }^{37}$ (dalej zw. u.o.a.n.) ${ }^{38}$. Oczywiście nie jest to równoznaczne $\mathrm{z}$ całkowitym odrzuceniem zastosowania regulacji u.d.i.p. W jednym ze swoich wyroków NSA stwierdził, że: „Informację udzieloną w trybie u.d.i.p stanowić mogą jedynie wiadomości o projektowanych aktach prawnych czy aktach nieogłoszonych"39. A zatem treść ostatecznego miejscowego planu zagospodarowania przestrzennego, wyrastająca poza wskazane założenie, neguje jego udostępnienie w trybie regulacji u.d.i.p.

37 Zob. Dz.U. 2011 Nr 197, poz. 1172 ze zm.

38 Trzeba jednak podkreślić, że część tekstów aktów prawnych nie jest udostępniana w trybie u.o.a.n. - zob. też G. Wierczyński, Pojęcie informacji publicznej w świetle ustawy o dostępie do informacji publicznej, „Gdańskie Studia Prawnicze - Przegląd Orzecznictwa” 2005, nr 1-2, s. 55.

39 Zob. Postanowienie NSA z dnia 24 stycznia 2006 r. (I OSK 928/05). 
W prowadzonych rozważaniach nad zagadnieniem udostępniania informacji publicznych warto także odnieść się do kwestii rejestrów publicznych, o których mowa w art. 31 ust. 1 oraz art. 57 ust. 2, ust. 2 ust. 3 u.p.i.z.p. Chodzi w tym wypadku o następujące rejestry, a mianowicie:

- $\quad$ rejestr planów oraz wniosków o ich sporządzenie prowadzony przez wójta, burmistrza, prezydenta miasta;

- $\quad$ rejestr wydanych decyzji o warunkach zabudowy prowadzony przez wójta, burmistrza, prezydenta miasta;

- rejestr wydanych decyzji o ustaleniu lokalizacji inwestycji celu publicznego o znaczeniu krajowym wojewódzkim prowadzony przez marszałka województwa;

- $\quad$ rejestr decyzji o ustaleniu lokalizacji inwestycji celu publicznego o znaczeniu powiatowym i gminnym prowadzony przez wójta, burmistrza, prezydenta miasta;

- $\quad$ rejestr decyzji o ustaleniu lokalizacji inwestycji celu publicznego na terenach zamkniętych prowadzony przez wojewodę ${ }^{40}$.

Co istotne, $\mathrm{z}$ istnieniem i prowadzeniem niniejszych rejestrów jest ściśle powiązana instytucja jawności formalnej. Polega ona na prawnym zagwarantowaniu każdemu lub określonym osobom dostępu do treści rejestru $\mathrm{w}$ celu zapoznania się $\mathrm{z}$ treścią zawartych $\mathrm{w}$ nim informacji. $\mathrm{W}$ tym znaczeniu zasada jawności jest równoznaczna z zasadą dostępności do rejestru $^{41}$. Trzeba jednak podkreślić, że niniejsza zasada nie podlega realizacji przy użyciu środków prawnych przewidzianych ogólną procedurą udo-

40 Wzór rejestru decyzji o warunkach zabudowy oraz wzór decyzji o ustaleniu lokalizacji inwestycji celu publicznego określa Rozporządzenie Ministra Infrastruktury z dnia 13 maja 2004 r. w sprawie wzoru rejestru decyzji o warunkach zabudowy oraz wzorów rejestrów decyzji o ustaleniu lokalizacji inwestycji celu publicznego (Dz.U. $\mathrm{Nr}$ 130, poz. 1385).

41 W ujęciu formalnym jawność formalna rejestrów obejmuje: uprawnienie do wglądu do rejestru i bezpośredniego zapoznania się z treścią dokonywanych w nim wpisów oraz złożonych dokumentów, uprawnienie do samodzielnego sporządzania notatek i odpisów, uprawnienie do żądania wydania odpisów, wyciągów i zaświadczeń potwierdzających urzędowo treść wpisu w rejestrze lub treść złożonych dokumentów, obowiązek ogłaszania niektórych danych objętych rejestrem publicznym w gazetach lub innych wyznaczonych do tego publikatorach - zob. T. Stawecki, Rejestry publiczne. Funkcje instytucji, Warszawa 2005, s. 101. 
stępniania informacji publicznej ${ }^{42}$. W trybie uregulowań u.d.i.p. podlega udostępnieniu informacja nie tyle o danych czy informacjach zawartych $w$ rejestrze, a raczej informacja o prowadzonych rejestrach, ewidencjach i archiwach oraz o sposobach i zasadach udostępniania danych w nich zawartych. I mimo braku bezpośredniego wskazania niniejszej materii w regulacjach u.p.i.z.p. zasługuje ona również na uwypuklenie, albowiem posiada znaczenie z punktu widzenia konstytucyjnego prawa uzyskiwania informacji. Jest środkiem prawnym, przy pomocy którego jednostki mogą pozyskiwać informacje o podmiotach oraz o ich działalności i w efekcie mogą czynić praktyczny użytek z zagwarantowanego w art. 61 ust. 1 Konstytucji prawa o charakterze podstawowym.

Ponadto $\mathrm{w}$ prowadzonych rozważaniach nie bez znaczenia pozostaje również fakt projektowanych zmian w zakresie regulacji prawa budowlanego i planowania przestrzennego. Chodzi w tym wypadku o przygotowany, a następnie przyjęty przez Komisję Kodyfikacyjną Prawa Budowlanego projekt tzw. Kodeksu urbanistyczno-budowlanego ${ }^{43}$. Wejście w życie regulacji zawartych w przedmiotowym kodeksie spowoduje utratę mocy szeregu aktów prawnych aktualnie reagujących problematykę procesu budowlanego oraz planowania przestrzennego ${ }^{44}$. Wyjątek w niniejszym zakresie ma dotyczyć wyłączenia spod regulacji kodeksowych uregulowań odnoszących się do planowania „wykraczającego poza granice” obszaru gminy, czyli tzw. planowania ponadlokalnego. Potwierdzeniem niniejszego jest wynikające $\mathrm{z}$ art. 1 uregulowanie, w świetle to którego kodeks ma normować sprawy kształtowania i realizacji lokalnej polityki przestrzennej. Co istotne, owe zamierzenie sprowadzające się do „wykluczenia” uregu-

42 Jawność formalna rejestrów i ewidencji realizuje się za pomocą swoistych środków prawnych przewidzianych w aktach prawnych normujących poszczególne rodzaje rejestrów i ewidencji.

43 Zob. Projekt Kodeksu urbanistyczno-budowlanego - wersja podstawowa przyjęta przez Komisję Kodyfikacyjną Prawa Budowlanego w dniu 16 kwietnia 2014 r., Warszawa 2014 r., www.mir.gov.pl/Budownictwo/Komisja_Kodyfikacyjna_Prawa_Budowlanego/ Documents/Kodeks_urbanistyczno_budowlany_projekt_podstawowa_16_04_2014_ jednolity.pdf. (10.05.2014).

44 W szczególności chodzi w tym wypadku o regulacje ustawy z dnia 7 lipca 1994 r. Prawo budowlane (Dz.U. 2013 poz. 1409 ze zm.) oraz ustawy z dnia 27 marca 2003 r. o planowaniu i zagospodarowaniu przestrzennym (Dz.U. 2012 poz. 647 ze zm.). 
lowań odnoszących się do planowania przestrzennego województwa czy też uregulowań odnoszących się do obszaru planowania przestrzennego całego kraju z przyjętego projektu z jednej strony można rozpatrywać jako próbę podkreślenia znaczenia polityki planistycznej na poziomie lokalnym, z drugiej jednakże strony prowadzi do podzielenia regulacji i ich rozproszenia pomiędzy odrębne akty normatywne, co nie do końca można ocenić pozytywnie. Wprawdzie celem projektowanych zmian zawartych w kodeksie jest przede wszystkim wypracowanie takich instytucji prawnych, które umożliwiłyby sprawniejsze inwestowanie oraz szybszą realizację procesu budowlanego, niemniej jednak nie powinno ono odbywać się kosztem wprowadzenia zamętu w zakresie rozmaitego umiejscowienia uregulowań dotyczących jednej (tej samej) tematyki, niezależnie od jej terytorialnego zastosowania.

Z punktu widzenia prowadzonych rozważań na szczególną uwagę zasługują tego rodzaju zmiany w planowaniu przestrzennym, na płaszczyźnie to których uwidacznia się występowanie instrumentów ochrony interesu prawnego jednostki w związku z instytucją dostępu do informacji publicznej. Planowe gospodarowanie przestrzenią stanowi dział III projektu Kodeksu urbanistyczno-budowlanego. Co istotne, już na samym początku (art. $18 \$ 1$ ) omawianego projektu dochodzi do podkreślenia znaczenia zasady jawności w zakresie kształtowania i realizacji lokalnej polityki przestrzennej. Uzupełnieniem niniejszego jest przedstawione w art. 19 uregulowanie odnoszące się do kontroli społecznej jako procesu, któremu ma podlegać realizacja zadań publicznych w zakresie kształtowania i realizacji polityki przestrzennej.

Uregulowania przygotowanego projektu kodeksu stanowią o występowaniu aktów planowania przestrzennego, do których należą: studium uwarunkowań i kierunków zagospodarowania przestrzennego, miejscowy plan zagospodarowania przestrzennego oraz miejscowe przepisy urbanistyczne. Ich sporządzenie wymaga uwzględnienia urbanistycznych standardów planistycznych oraz opracowania ekofizjograficznego jako dokumentu określającego warunki równowagi przyrodniczej oraz racjonalnej gospodarki zasobami środowiska. Co ważne, już na tym etapie uwidacznia się aspekt upubliczniania wiedzy publicznej, albowiem w świetle projektowanej zmiany organ wykonawczy przynajmniej raz na 4 lata ma obowiązek sporządze- 
nia okresowej oceny aktualności opracowania ekofizjograficznego, a następnie podania jej wyników do publicznej wiadomości ${ }^{45}$. Przechodząc z kolei do samego aspektu procedury planistycznej, na płaszczyźnie której dostrzegalnym stają się elementy rozpatrywane na gruncie niniejszego opracowania jako instrumenty ochrony interesu prawnego jednostki w ramach dostępu do informacji publicznej, można zauważyć występujące podobieństwa zarówno w zakresie ich występowania, jak również ich zastosowania.

Niewątpliwie w dążeniu do opracowania zbiorczego katalogu wszystkich tych elementów, które wyczerpują znamiona instrumentów ochrony w ramach omawianej instytucji udostępniania wiedzy publicznej, na pierwszy plan wysuwa się kwestia wyłożenia do publicznego wglądu projektu aktu planowania oraz instytucja podawania do publicznej wiadomości (przy jednoczesnym dokładnym określeniu, na czym ono ma konkretnie polegać). W świetle bowiem uregulowań zawartych w projekcie sprowadza się ono do obwieszczenia stosownych informacji w siedzibie organu oraz do ogłoszenia informacji w prasie miejscowej. Ma ono zastosowanie w kontekście:

- upubliczniania informacji o podjęciu uchwały o przystąpieniu do sporządzenia aktu (studium, planu miejscowego) lub przystąpienia do podjęcia jego zmiany;

- upublicznienia informacji o zgłoszonych propozycjach przez społeczeństwo oraz o wynikach przeprowadzonych analiz;

- upublicznienia informacji o wyłożeniu projektu aktu planowania przestrzennego do publicznego wglądu;

- upublicznienia informacji o możliwości składania uwag do projektu aktu planowania przestrzennego, prognozy oddziaływania na środowisko, prognozy skutków finansowych oraz projektu scalenia i podziału nieruchomości;

- upublicznienie informacji o zgłoszonych uwagach i przebiegu dyskusji publicznej oraz o sposobie rozstrzygnięcia zgłoszonych uwag wraz $\mathrm{z}$ uzasadnieniem;

- upublicznienie dokonanej przez wójta, burmistrza, prezydenta miasta prognozy rozwoju funkcjonalno-przestrzennego gminy oraz pro-

45 Zob. art. $70 \$ 3$ - Projektu Kodeksu urbanistyczno-budowlanego - wersja podstawowa, op.cit. 
gramów sporządzania planów miejscowych i miejscowych przepisów urbanistycznych.

Uzupełnieniem niniejszej formy, posiadającej niejako ogólny charakter, bo skierowanej do ogółu społeczności lokalnej zamieszkującej dane terytorium, jest instrument pisemnego zawiadomienia właścicieli i użytkowników wieczystych nieruchomości położonych na obszarze wymagających zmian w ukształtowaniu granic nieruchomości wskazanych w uchwale o przystąpieniu do sporządzenia planu miejscowego, jak również pozyskanie zgody od właścicieli użytkowników wieczystych zabudowanych części nieruchomości planowanych do scalenia i podziału ${ }^{46}$. Ponadto na wyróżnienie zasługuje fakt określonej w projekcie kodeksu publikacji w dzienniku urzędowym województwa ${ }^{47}$. Niniejsze uregulowanie wskazuje na kategorię zbiorczą, tj. na kategorię aktu planowania przestrzennego, jako dokumentu kwalifikującego się do przedmiotowego procesu upublicznienia. Tym samym w sposób dorozumiany, m.in. poprzez brak konkretnego wskazania, który z niniejszych aktów planowania podlega publikacji, czy też z przeciwnej strony poprzez brak wyraźnego wykluczenia któregokolwiek z wymieniowych, a zawartych $\mathrm{w}$ definicji aktu planowania przestrzennego z procesu publikacji, znacznie rozszerza katalog dokumentów podlegających ogłoszeniu przy użyciu niniejszego sposobu. Co istotne, należy w tym miejscu zwrócić uwagę, że przedstawiony aspekt publikacji aktu planowania przestrzennego w dzienniku urzędowym województwa stanowi istotną odmienność w porównaniu do aktualnie obowiązujących regulacji w omawianym zakresie. Przygotowany bowiem projekt kodeksu w uogólniony sposób stanowi o upublicznieniu przyjętego aktu planowania przestrzennego $\mathrm{w}$ dzienniku urzędowym danego województwa, podczas gdy na gruncie obowiązujących uregulowań tego rodzaju kwestia została w zupełności wyłączona spod regulacji u.p.i.z.p. i odnosi się wyłącznie do miejscowego planu zagospodarowania przestrzennego jako aktu prawa miejscowego. Niewątpliwe zamierze-

46 Chyba że chodzi o nieruchomości wchodzące w skład obszarów rewitalizacji oraz znajdujących się w granicach obszarów zabudowy, albowiem w ich przypadku zgoda na scalenie lub podział nie jest wymagana - zob. art. $162 \$ 2$ Projektu Kodeksu urbanistyczno-budowlanego - wersja podstawowa, op.cit.

47 Zob. art. 81 Projektu Kodeksu urbanistyczno-budowlanego - wersja podstawowa, op.cit. 
nie dotyczące rozszerzenia zakresu przedmiotowej publikacji w dzienniku urzędowym ${ }^{48}$ przy jednoczesnym podkreśleniu znaczenia miejscowego planu zagospodarowania przestrzennego jako aktu prawa miejscowego należy ocenić pozytywnie. Znacząco bowiem poszerza zakres wiedzy publicznej, z treścią której może zapoznać się każdy obywatel, w szczególności zaś członek danej społeczności lokalnej, a ściślej mówiąc rozszerza katalog możliwości informacyjnych, z jakich może skorzystać zainteresowana jednostka.

Reasumując całokształt realizowanej procedury planistycznej (i to zarówno, jeśli chodzi o aktualnie obowiązujące uregulowania, jak i również projektowane zmiany w niniejszym zakresie), można wskazać, że ona sama w swej istocie wyraźnie podkreśla znaczenie instytucji dostępu do informacji publicznej jako kategorii ochrony interesu prawnego jednostki. Skłonność do poszukiwania i chęć zdobycia wiedzy stanowią rezultat podstawowej potrzeby egzystencjalnej jednostki. Chodzi w tym wypadku o zaspokojenie tzw. potrzeby poznania w drodze umożliwienia dostępu do tych informacji, które są jednostce potrzebne w danym miejscu i w danym czasie. Współcześnie dostęp do informacji publicznej jako pewnego rodzaju instytucja prawna stanowi nie tylko warunek istnienia demokratycznego państwa prawa, ale przede wszystkim jest sprawnym narzędziem realizacji licznych uprawnień obywatelskich. A zatem działanie ustawowo określonych podmiotów zmierzające do zaspokojenia interesu informacyjnego jednostki otwiera możliwości do podejmowania przez nią dalszych działań dla spełnienia własnych celów i ochrony własnej osoby. Uwidacznia się to wyraźniej wówczas, gdy w grę wchodzi udostępnianie przy użyciu środków tzw. nowej technologii, które już w swoim założeniu mają ułatwiać i przyśpieszać uzyskanie wiedzy objętej oczekiwaniami informacyjnymi jednostki. Zatem dokładne określenie, kiedy powszechne prawo do informacji przysługuje, jaką grupę spraw obejmuje swoim zakresem, jak również precyzyjne ustalenie sposobów jego realizacji zarówno na gruncie regulacji ogólnych, jak i na płaszczyźnie konkretnych dziedzin administracji publicznej stanowi podstawowy warunek społeczeństwa informacyjnego.

48 Zgodnie z treścią definicji aktu planowania przestrzennego, która została zawarta w art. 3 pkt. 1 projektu Kodeksu urbanistyczno-budowlanego, chodzi w tym wypadku o studium uwarunkowań i kierunków zagospodarowania przestrzennego oraz o przepisy urbanistyczne. 
Jak wynika z przedstawionej analizy, ochrona interesu prawnego jednostki w ramach dostępu do informacji w regulacjach u.p.i.z.p. sprowadza się do realizacji ustawowo określonych zobowiązań przez organy wykonawcze jednostek samorządu terytorialnego. Co ważne, niniejsze zobowiązania łącznie tworzą płaszczyznę wypełniania obowiązku informacyjnego na gruncie planowania i zagospodarowania przestrzennego kraju. Same zaś elementy określane w niniejszych rozważaniach jako instrumenty ochrony interesu informacyjnego jednostki zasadniczo odbiegają od elementów występujących na gruncie regulacji u.d.i.p. Dominujące znaczenie odgrywa w tym wypadku (niewystępująca na gruncie regulacji ogólnych) forma podawania do publicznej wiadomości. Z jednej strony jest ona elementem udostępniania wiedzy i kształtowania opinii publicznej. Z drugiej z kolei strony poprzez dostarczanie niezbędnych danych zapewnia ochronę interesów prawnych jednostek danej wspólnoty samorządowej. Co więcej, niniejsze założenie posiada swoje uzasadnienie, mimo iż w zakresie przedmiotowego procesu uświadamiania nie można mówić o skierowaniu instrumentu do ściśle określonych (pojedynczych) jednostek.

\section{Literatura}

Aleksandrowicz T. R., Komentarz do ustawy o dostępie do informacji publicznej, Warszawa 2008.

Bernaczyk M., Jabłoński M., Wygoda K., Biuletyn informacji publicznej. Informatyzacja administracji, Wrocław 2005.

Bernaczyk M., Obowiązek bezwnioskowego udostępniania informacji publicznej, Warszawa 2008.

Dolnicki B., Zasady jawności i dostępu do informacji publicznej jako czynnik przeciwdziałania biurokratyzowaniu się administracji, [w:] Biurokracja, III Międzynarodowa Konferencja Naukowa, Krynica, 2-4 czerwca 2006 r., Rzeszów 2006.

Gardocka T., Obywatelskie prawo do informacji, Warszawa 2008.

Jabłoński M., Wygoda K., Dostęp do informacji i jego granice, Wrocław 2002.

Jabłoński M., Wygoda K., Konstytucyjne uprawnienia jednostki w sferze informacyjnej, [w:] Sześć lat Konstytucji Rzeczpospolitej Polskiej. Doświadczenia i inspiracje, red. L. Garlicki, A. Szmyt, Warszawa 2003.

Jabłoński M., Wygoda K., Ustawa o dostępie do informacji publicznej. Komentarz, Wrocław 2002. 
Jaśkowska M., Dostęp do informacji publicznej. Zagadnienia wybrane (materiał na konferencje sędziów NSA), Popowo 14-16 października 2002, Warszawa 2002.

Leoński Z., Materialne prawo administracyjne, Warszawa 2009.

Sitniewski P., Ustawa o dostępie do informacji publicznej. Komentarz, Wrocław 2011.

Stawecki T., Rejestry publiczne. Funkcje instytucji, Warszawa 2005.

Wierczyński G., Pojęcie informacji publicznej w świetle ustawy o dostępie do informacji publicznej, „Gdańskie Studia Prawnicze - Przegląd Orzecznictwa” 2005, nr 1-2.

Zaremba M., Prawo dostępu do informacji publicznej. Zagadnienia praktyczne, Warszawa 2009. 